Florida International University FIU Digital Commons

$8-2011$

\title{
The Basis of Support for Hugo Chávez: Measuring the Determinants of Presidential Job Approval in Venezuela
}

\author{
Orlando J. Pérez, Ph.D \\ Central Michigan University
}

Follow this and additional works at: https://digitalcommons.fiu.edu/whemsac

\section{Recommended Citation}

Pérez, Ph.D, Orlando J., "The Basis of Support for Hugo Chávez: Measuring the Determinants of Presidential Job Approval in Venezuela" (2011). Western Hemisphere Security Analysis Center. 32.

https://digitalcommons.fiu.edu/whemsac/32 


\title{
The Basis of Support for Hugo Chávez:
}

Measuring the Determinants of Presidential Job Approval in Venezuela

\author{
Orlando J. Pérez, Ph.D \\ Central Michigan University
}

August 2011 


\section{THE WESTERN HEMISPHERIC SECURITY ANALYSIS CENTER}

WHEMSAC brings together a versatile and important Latin American network of traditional and non-traditional security experts from academia, business sectors, government ministries and private organizations. Its research capabilities provide Western Hemispheric leaders with a unique, real-time research and analysis on current issues. WHEMSAC is an innovative institutional model for conducting professional qualitative and quantitative research throughout the Americas at the national, regional and international levels within an open, independent, multi-disciplinary, and collaborative academic environment. The fusion of open source political, economic, and social expertise allows WHEMSAC to provide an exceptional, qualified approach to regional security insight with traditional intra-governmental analysis.

Applied Research Center

Florida International University

10555 W Flagler Street

Miami, FL 33174

whemsac.fiu.edu 


\title{
The Basis of Support for Hugo Chávez:
}

Measuring the Determinants of

Presidential Job Approval in

Venezuela

\author{
Orlando J. Pérez, Ph.D \\ Central Michigan University
}

August 2011

The views expressed in this research paper are those of the author and do not necessarily reflect the official policy or position of the US Government, Department of Defense, US Southern Command or Florida International University. 


\section{EXECUTIVE SUMMARY}

Since 1999, Venezuela has experienced a dramatic transformation of its political system with the coming to power of Hugo Chávez and his movement, known in Venezuela as Chavismo. Chávez has dismantled the previous political system and established neo-populist structures that rely on his personal appeal and the close collaboration of the armed forces. Chávez has relied heavily on significant support from the poor and those who felt economically and politically excluded by the "Punto Fijo system."

President Chávez has built an impressive record of electoral victories; winning every electoral contest except one since coming to power in 1999. He continues to receive relatively high levels of support among sectors of Venezuelan society. However, there is evidence of growing discontent with high crime rates, high levels of inflation, and significant corruption in the public administration. Using data from the AmericasBarometer surveys conducted in 2007, 2008 and 2010, this paper seeks to examine the basis of Chávez's popular support.

In general, the AmericasBarometer findings suggest that Venezuelans support for President Chávez is closely linked to the access to social programs and that as long as the government is able to fund these social programs or missions, particularly MERCAL and Barrio Adentro, it will possess an important tool to garner and sustain support for President Chávez. Our analysis, however, also indicates that evaluations of the national economic situation, more than crime or insecurity, are a key factor that could undermine support for the regime. 


\section{EXPLAINING THE RISE TO POWER OF HUGO CHÁVEZ}

From the transition to democracy in 1958 up until 1998, Venezuela had a peculiar democratic regime known as the "Punto Fijo system," named for a pact signed by key political actors during the transition. The system of "pacted" democracy derived its legitimacy from the capacity of the state to distribute resources and patronage among power contenders, particularly industry and organized labor. The pacts were financed through petroleum wealth that boomed until the economic crisis of the early 1980s. ${ }^{1}$ Oil wealth permitted the state to meet the demands of various groups without having to make hard choices. The government could pursue redistributive policies while preserving economic growth. As a consequence, a "culture of entitlement" developed. As McCoy et al. explain:

Venezuelan political culture is defined in large part by the rentier state, which has maintained social peace and political stability by distributing externally derived rents from oil profits, rather than relying on domestic taxation. In this way, the state has ameliorated social conflict and gained legitimacy from the hopes for social mobility and improved standards of living provided by

\footnotetext{
${ }^{1}$ Terry Lynn Karl, "Petroleum and Political Pacts: The Transition to Democracy in Venezuela," in Guillermo O'Donnell, Philippe C. Schmitter, and Laurence Whitehead (eds), Transitions from Authoritarian Rule: Latin America, (Baltimore. MD: Johns Hopkins University Press, 1986), pp. 196-219; Terry Lynn Karl, "The Venezuelan Petro-State and the Crisis of 'its' Democracy," in Jennifer McCoy, Andres Serbin, William C. Smith, and Andres Stambouli, Venezuelan Democracy under Stress, (Coral Gables, FL: North-South Center, University of Miami, 1995), pp. 33-58.
} 
oil wealth. The rentier state and the practice of protection, subsidies, and price controls from 1960-1980 also produced a culture of entitlement-a widely-held belief that oil is the national patrimony, that the country is rich, and that each individual deserves their fair share. ${ }^{2}$

In order to maintain economic expansion the government had to borrow money in the international market based on the strength of its ability to generate many times the value of these obligations with its productive oil industry. By 1981, however, Venezuela's luck began to run out. Oil revenues declined from 1981 to 1985 from 20 billion to 14 billion U.S. dollars. In 1986, they went down to 8.7 billion. ${ }^{3}$ Real wages that had exhibited a steady increase from 1968 to 1978, declined precipitously from 1978 to $1990 .^{4}$ The year 1989 was particularly disastrous for the Venezuelan economy. Inflation rose to 84 percent for the year, until then the highest in the history of the country. Economic output, as measured by GDP, declined 8.6 percent in real terms, while salaries shrank by 11 percent. ${ }^{5}$ In this context, Carlos Andres Pérez, the newly elected president, implemented a harsh neoliberal restructuring policy that drastically cut state subsidies

2 Jennifer McCoy, Jeff Davies, and Paul Foote, "Reluctant Reformers:

Explaining Privatization in Venezuela and Uruguay," Paper presented at the Meeting of the Latin American Studies Association, Chicago, Ill, 1998 , p. 14.

${ }^{3}$ Daniel Hellinger, Venezuela, Tarnished Democracy, (Boulder, CO:

Westview Press, 1991), p. 123.

${ }^{4}$ Brain Crisp, Daniel H. Levine and Juan Carlos Rey, "The Legitimacy Problem," in Venezuelan Democracy under Distress, Jennifer McCoy, et al (previous cit., pp. 139-172).

${ }^{5}$ Moises Naim, Paper Tigers and Minotaurs: The Politics of Venezuela's Economic Reforms, (Washington, D.C.: Carnegie Endowment for International Peace, 1993), pp. 59-60. 
and social welfare spending. The military was hard hit by the program in declining real wages and reduced resources for modernization.

Chavismo itself had its beginnings in the Bolivarian Revolutionary Movement 200, or MBR 200 (Movimiento Bolivarian Revolucionario 200), a clandestine organization within the armed forces founded in 1983 by Hugo Chávez and fellow junior officers. Using Simón Bolivar's ideals, Chávez and his colleagues rallied the concerns of other military officers for the coup attempt of 4 February 1992. The rebellion, and another led by senior officers on 27 November 1992, shook the Venezuelan political establishment to its core, but the puntofijista system held. Public opinion surveys taken before and after the coup attempt indicated that while the public opposed the traditional parties, only a quarter to a third supported a military-led government. ${ }^{6}$ However, during the next six years the economic and political situation of the country did not improve and by the elections of December 1998 the public was prepared to exercise an electoral coup by electing Hugo Chávez as president. In a hard-fought campaign in which they promised to end the old political system and call for a constituent assembly, Chávez and his new party, Movimiento $V$ República (or MVR) steadily increased in the polls and won the presidential election with a solid 54 percent of the vote.

\footnotetext{
${ }^{6}$ Andrew Templeton, "The Evolution of Popular Opinion," in Louis Goodman et al, (eds), Lessons of the Venezuelan Experience (Washington, D.C: The Woodrow Wilson Center, 1996); Nelson Villasmil, La Opinión pública del venezolano actual, (Caracas: UCAB/Cátedra Fundacional Carlos E. Frías, 2000).
} 


\section{NEO-POPULISM AS THE UNDERLYING PRINCIPLE OF THE REGIME}

Brian Loveman and Thomas Davies argue that, "In the 1960s and 1970s professional military officers in Latin America scanned the panorama of the hemisphere's history and blamed the ineptitude and corruption of civilian politicians as well as the imported institutions of liberal democracy for the wretched conditions in their region."7 This appears to be the same motivation in Venezuela. An alienated population fell under the charm of the charismatic paratrooper who was willing to sacrifice his life for the country in a heroic effort to take over the government and "save" the nation from a corrupt political system.

Chávez has proclaimed himself "an interpreter of the Venezuelan peoples' demands," one who has been called upon by historic forces beyond his control to carry out this mission. Norberto Ceresole, an argentine political thinker, describes the political system created by Chávez as "postdemocratic." The system is characterized by the concentration of power in the hands of a caudillo that embodies the aspirations of the masses. Ceresole argues that the new "Venezuelan system" emerges from the fundamental relationship "caudillo-masses," one that is rooted in the history of Latin America. The system is the product of a revolutionary model that pivots around the basic relationship between a national caudillo and a mass of people representing an absolute majority that chooses him, personally, as their representative. For Ceresole, the relationship between the masses and the caudillo is not one

\footnotetext{
${ }^{7}$ Brian Loveman and Thomas M. Davies (eds), The Politics of Antipolitics: The Military in Latin America (revised and updated), (Wilmington, DE: Scholarly Resources, 1997), p 3.
} 
of ideas or institutions, but rather a "physical" one embodied by the fusion of the man with his people (i.e., the man becomes the people and the people become the man). ${ }^{8}$ Elections bestow an absolute mandate on the leader to implement policy as he sees fit. There cannot be any institutional impediments to his actions because that would undermine the people's will. This description sounds similar to the notions embodied in Latin America's traditional populism, however, for Ceresole, Chávez represents a "welcome departure from the global acceptance of liberal democracy," which Ceresole sees as an imposition from the West and not in tune with the traditional cultural and political structures of Latin America.

Thus the Chávez "revolution" has systematically removed all the checks and balances required for liberal democracy. Dismantling liberal democracy was achieved in a two stage process: (1) elimination of the old political actors in a position to check the president; and (2) securing the loyalty or subordination of the new actors. The means for the first stage was the National Constituent Assembly (Asamblea Nacional Constituyente--ANC), which was authorized by a referendum in April 1999 and elected in July 1999, finished with its draft in three months, had the new constitution ratified on 15 December 1999, and disbanded itself on 31 January 2000. The greatest advantage to the ANC was its ability to eliminate checks on the president in the short term. Only a constituent assembly would have the power to neutralize the opposition-controlled Congress elected in November 1998. The old Congress allowed itself to be marginalized soon after the ANC was seated, and it formally

\footnotetext{
${ }^{8}$ Norberto Ceresole, "El modelo venezolano o la posdemocracia: Caudillo, apóstoles, pueblo." El Universal Digital, (http://politica.eud.com/1999/03/08/ceresole.html), 11 January 1999.
} 
ceased to exist the day the 1999 constitution was ratified. That date also marked the elimination of the Supreme Court (Corte Suprema de Justicia) and the beginning of the second stage, as the ANC appointed a new Supreme Justice Tribunal (Tribunal Supremo de Justicia), a new electoral council, and a new Comptroller General, all of whom were allies of Chávez. At the same time, the ANC designated an un-elected National Legislative Committee to take the place of the legislature until new elections could be held, and appointed a commission that purged hundreds of judges from the courts.

This transitional regime continued in power until August 2000, when new officials elected in July were seated. Chávez himself was reelected with a 56.9 percent landslide, and his allied parties won at least 99 of 165 seats in the new unicameral National Assembly. In November 2000 they granted the president sweeping powers to issue decree-laws in areas ranging from economic development to land reform. A few governors remained affiliated with opposition parties, but the federal government undermined their power by reducing funding for state and local governments. Between December 1998 and August 2000, therefore, Chávez removed, co-opted, or severely weakened all possible checks from other branches and levels of government.

\section{ChALLENGING CHAVISMO}

A deepening economic recession, coupled with Chávez's personalistic rule and incendiary rhetoric, caused many Venezuelans and even some of his political allies to lose faith in the movement. By the end of 2001, the internal political situation in Venezuela was at a critical moment. ${ }^{9}$

\footnotetext{
${ }^{9}$ The discussion of the political situation before and after the April 2002 coup draws heavily from Orlando J. Pérez, "Chavismo and the
} 
Political opposition to the president had been mounting since December 10, 2001, when civic groups, unions, and business organizations staged the first nationwide strike to express discontent with the government's decision to decree the adoption of a large package of economic reform measures.

In a move widely seen as a sign of growing discontent within the armed forces, during the month of February 2002 a series of high-ranking officers publicly criticized the government. On February 7, Air Force Colonel Pedro Soto called the regime "fascist" and "totalitarian." While Colonel Soto claimed to represent "75 percent of the officers, noncommissioned officers, and troops," there were no signs of a deeper move against the President. However, the next day Captain Pedro Flores called the president "undemocratic." On February 18, Vice-Admiral Carlos Molina Tamayo accused Chávez of harming the national interest. And on February 25 Brigadier General Roman Gomez said "There is a crisis in every sector of power...they [the government] want to split us into two groups...this division has been carried into the armed forces as well." The General went on to say, "Our loyalty is to the nation, not with the current administration."10

President Chávez's decision to dismiss several board members at the state-owned petroleum company, Petróleos de Venezuela S.A. (PDVSA), on April 7 and the subsequent work stoppage at key oil production facilities, due to a renewed nationwide strike on April 10 forced PDVSA to declare that it would not be able to comply with contractual

Transformation of Civil-Military Relations in Venezuela," South Eastern Latinamericanist, (Summer 2002): pp. 12-33.

10 "Chávez unmoved as officers desert," $B B C$

News, (http://news.bbc.co.uk/hi/english/world/americas/), February 26, 2002. 
crude oil and product supply commitments with its international clients. The increased prospects that the oneday nationwide work stoppage could turn into an indefinite strike, and an escalation of violence that resulted in 15 deaths and 315 injured on April 11, prompted a military coup and the arrest of President Chávez. The military installed an interim government led by Pedro Carmona Estanga, a business leader. A combination of overreaching by the new government, popular protests in favor of the return of Chavez, and divisions within the military led to a collapse of the interim government and Chavez returned to power on April 13, 2002.

Chávez reacted forcefully to this turn of events, announcing new measures to reinvigorate the "revolution," calling for the creation of local, neighborhood groups known as Círculos Bolivarianos (Bolivarian Circles). These efforts proved highly successful, as over two million Venezuelans organized Círculos and other pro-Chávez organizations in their communities. The Círculos provided a basis for popular opposition to the attempted coup of 2002, and eventually for an electoral campaign.

Rising oil prices provided Chávez an opportunity to establish a series of social programs that became the basis for a radical new direction in government social policy, and significantly improved the president's public approval ratings. The new programs, called Misiones (Missions), drew on billions of dollars in oil revenues to provide free health care, remedial education, basic foodstuffs, plus occupational training and development loans to micro-industrial and rural cooperatives.

While feelings of frustration lingered and allowed the opposition to successfully call a presidential recall election 
in 2004, by the time the election occurred in August of that year Chávez had regained his popular support and won with 58 percent of the vote. In subsequent local elections in October 2004, Chavista candidates captured nearly every seat. And in the 2005 national legislative elections, a decision by the opposition to abstain resulted in a complete victory for Chávez. As a result, the legislature no longer had any opposition members. The regime then pushed a radical agenda set of reforms labeled "Socialism of the Twenty-First Century." 11 These reforms included additional nationalization of vital industries, deepening the role and extent of the Missions, creation of Community Councils, increasing the role of local radio and TV, and the creation of the United Socialist Party of Venezuela (Partido Socialista Único de Venezuela, PSUV).

In large part because of the economic rebound and attention to social programs, Chávez was reelected to another six-year term in December 2006 with almost 63 percent of the vote. After his reelection the regime radicalized further, as evidenced by the May 2007 closure of a popular Venezuelan television station that was critical of the government, Radio Caracas Television (RCTV). The closure of RCTV sparked

\footnotetext{
${ }^{11}$ Twenty-first century socialism is the brainchild of Heinz Dietrich Steffan, a German professor, in his book "El Socialismo del Siglo XXI" published in 2000. Dietrich proposes a new kind of socialism with four basic institutions: The first institution is the equivalence economy. Under this system, value is determined by those who create it, instead of the market. Value replaces price. The second institution is participative democracy, which uses the plebiscite to decide important questions that concern its citizens. The third institution is basic organizations, that is, the political or social organizations closest to the community that they serve. The fourth institution is development or structuralism, an economic theory that holds that the core industrial center with an agricultural periphery produces underdevelopment and increases the gap between developed and underdeveloped nations.
} 
significant protests and worldwide condemnation. Chávez also proposed a far-reaching constitutional amendment package that would have consolidated and deepened the social reforms, as well as provide for unlimited reelection for the president. The amendments were defeated by a close margin in a December 2007 national referendum. The cloture of RCTV and the constitutional referendum saw the emergence of University students as the vanguard of opposition to the regime. This coincided with a fragmentation of the political opposition.

State and local elections held in November 2008 revealed a mixed picture of support for the government and the opposition. Pro-Chávez candidates won 17 of the 22 governors' races, while the opposition won governorships in three of the country's most populous states, Zulia, Miranda and Carabobo, as well as the states of Nueva Esparta and Táchira. At the municipal level, pro-Chávez candidates won over 80 percent of the more than 300 mayoral races, while the opposition won the balance. Among the opposition's mayoral successes were races for the metropolitan mayor of Caracas, four out of the five smaller municipalities that make up Caracas (including the poor municipality of Sucre), and the country's second-largest city, Maracaibo. ${ }^{12}$

In the aftermath of the state and municipal elections, President Chávez announced that he would move ahead with another referendum to change the constitution to lift the twoterm limit on the presidential office. The referendum was scheduled for February 15, 2009, and various polls indicated

\footnotetext{
${ }^{12}$ Tyler Bridges, "Chávez Allies Score Big Wins in Venezuela Elections," Miami Herald, November 24, 2008; Simon Romero, "Venezuelan Opposition Gains in Several Crucial Elections," New York Times, November 24, 2008.
} 
that the vote would be close. Ultimately, with a participation rate of 70 percent Venezuelans approved the constitutional reform with almost 55 percent voting for it and 45 percent voting against it. ${ }^{13}$ President Chávez claimed the vote was a victory for the Bolivarian Revolution, and promised he would seek reelection in 2012. ${ }^{14}$ The president's support among many poor Venezuelans, who have benefited from increased social spending and programs, was an important factor in the vote.

Elections for the 165-member National Assembly were held on September 26, 2010, and pro Chávez supporters won 98 seats while opposition parties obtained $67 .{ }^{15}$ Nationwide participation in the elections was high, with 66.45 percent participation, but lower than the 75 percent participation in the 2006 presidential race.

The results of the legislative elections could be an indication that President Chávez will face a tough reelection bid in 2012. The results were significant for the opposition not only because they denied President Chávez a two-thirds majority, but because the opposition will now have a voice in the National Assembly. Nevertheless, while the opposition now has a voice in the legislature, it is unclear how united the multi-party opposition will be, or how effective it will be in presenting itself as a viable political alternative that is appealing to the Venezuelan electorate. While support for President Chávez diminished in 2009 and 2010 for a variety of reasons - such as high crime, inflation, shortages of some

\footnotetext{
${ }^{13}$ Results are available at:

http://www.cne.gov.ve/divulgacion referendo enmienda_2009/.

${ }^{14}$ Juan Forero, "Chávez Wins Removal of Term Limits," Washington Post, February 16, 2009.

15 "Venezuela Country Report," Economist Intelligence Unit (EIU) November 2010.
} 
food items and other consumer products, and repression of political opponents - his popularity reportedly has risen to about 50 percent in February 2011, more than any other political figure in the country.

\section{DETERMINANTS OF PRESIDENTIAL APPROVAL}

So, what are the factors that explain support for President Hugo Chávez? This section uses data from the AmericasBarometer surveys to examine the evolution of and factors that explain presidential approval rates for Hugo Chávez.

The AmericasBarometer is an integral part of the Latin American Public Opinion Project (LAPOP) at Vanderbilt University. ${ }^{17}$ The AmericasBarometer is an effort by LAPOP to measure democratic values and behaviors in the Americas using national probability samples of voting-age adults. The AmericasBarometer has been conducted every two years since 2004. In 2004, the first round of surveys was implemented with eleven participating countries; the second took place in 2006-07 and incorporated 22 countries throughout the hemisphere. In 2008, 24 countries throughout the Americas were included. Finally, in 2010 the number of countries increased to 26. All reports and respective data sets are available on the LAPOP website:

\footnotetext{
16 "Revolution by Numbers," Latin American Andean Group Report, Latin American Newsletters, February 2011, RA-11-02.

${ }^{17}$ The author has been involved with the project since its inception in the early 1990s, and is a member of the project's Scientific Support Group, as well as country-team leader for Panama. The author wishes to thank Mitchell A. Seligson, director and founder of LAPOP, for generously permitting use of the Venezuela data.
} 
www.LapopSurveys.org. The Venezuelan surveys were conducted in $2007,{ }^{18} 2008^{19}$ and $2010 .{ }^{20}$

${ }^{18}$ The 2007 survey was conducted by Centro de Investigaciones en Ciencias Sociales (CISOR), with scientific direction being provided by Mitchell A. Seligson. The field work was carried out by Borge and Associates. For the purposes of this survey, the population of interest consisted of all Venezuelan citizens, 18 years or older residing in the country. The sample was self-weighted and was designed to be representative of the voting population in terms of gender, age and geographic distribution. The survey was a national probability design, with a total $\mathrm{N}$ of 1,510 and the country was stratified into six (6) regions: capital, zuliana, west, mid-west, east and Los Llanos. The complete sample of 1,510 is composed of $50.1 \%$ male respondents and $49.9 \%$ female, and its estimated margin of error is \pm 2.5 (at the $95 \%$ level). The complete questionnaire can be found at www.AmericasBarometer.org. ${ }^{19}$ The 2008 survey was conducted by Vanderbilt University and Centro de Investigaciones en Ciencias Sociales (CISOR) with field work being carried out by CEDATOS. Funding came from Interamerican Development Bank (IDB). The project used a national probability sample design of voting-age adults, with a total $\mathrm{N}$ of 1,500 people involving face-to-face interviews in Spanish. The data set can be best described as a complex sample design taking into account stratification and clustering. The sample was stratified by regions (capital, zuliana, west, mid-west, east and Los Llanos) and by urban and rural areas. The total number of respondents surveyed in urban areas is 1221 and 279 in rural areas. The estimated margin of error for the survey is \pm 2.53 .

${ }^{20}$ The 2010 survey was conducted by Vanderbilt University with the field work being carried out by CEDATOS. The 2010

AmericasBarometer received generous support from many sources, including UNDP, IADB, Vanderbilt U., Princeton U., Université Laval, U. of Notre Dame, among others. The project used a national probability sample design of voting-age adults, with a total $\mathrm{N}$ of 1,500 people. It involved face-to-face interviews conducted in Spanish. The survey used a complex sample design, taking into account stratification and clustering. The sample consists of six strata representing the six main geographical regions: Metropolitan area (capital), zuliana, west, mid-west, east and Los Llanos. Each stratum was further sub-stratified by urban and rural areas. A total of 1,440 respondents were surveyed in urban areas and 60 in rural areas. The estimated margin of error for the survey is \pm 2.53 . 
In order to measure approval of Chávez, the survey asks respondents "Speaking in general, how well is President Hugo Chávez performing his job." The wording of the question is: "M1. Y hablando en general del actual gobierno, diría usted que el trabajo que está realizando el Presidente Hugo Chávez es: [Leer alternativas] (1) Muy bueno (2) Bueno (3) Ni bueno, ni malo (regular) (4) Malo (5) Muy malo (pésimo) (8) NS/NR" (In general terms, would you say that the work done by President Chávez is: [read options] (1) very good (2) good (3) neither good, nor bad-regular (4) bad (5) very bad (terrible) (8) don't know/no answer.)

Figure 1 shows the distribution of responses for 2010. The data reveals that a plurality of Venezuelans in 2010, 43 percent, indicated that President Chávez's performance was "regular" or "neither good, nor bad." The rest of respondents are divided almost evenly between positive and negative evaluations, 28.1 percent say the performance is good or very good, and 28.9 percent that it is bad or very bad.

\section{Figure 1: Presidential Approval, 2010}

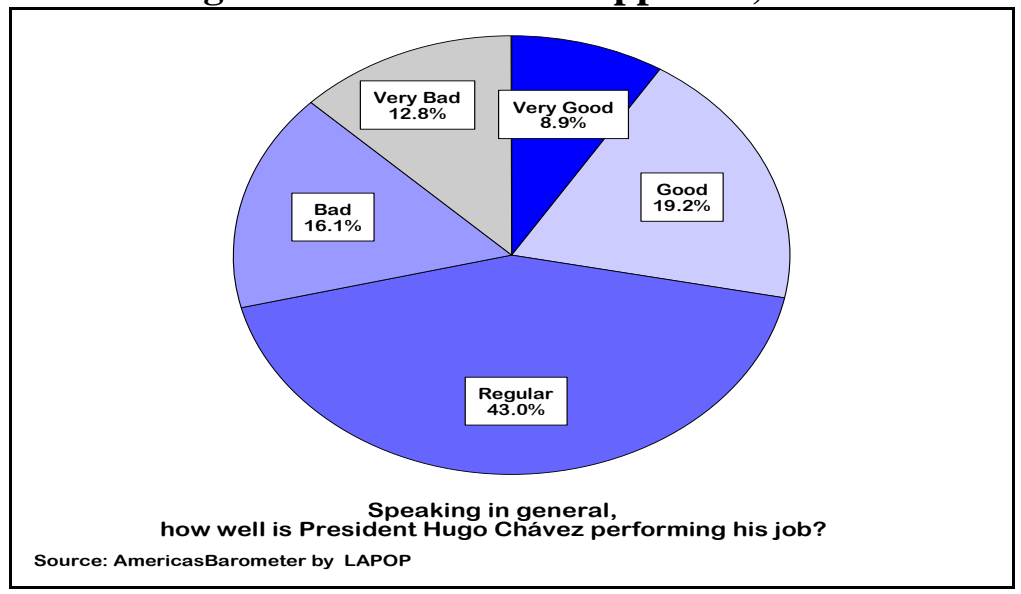


Figure $2^{21}$ presents results for presidential approval rates over the three rounds of the AmericasBarometer in Venezuela. The results show steady erosion in satisfaction with the performance of President Chávez, from an average approval of 57.1, on the 0-100 scale in 2007, to 48.8 in 2010. Since the mid-point of the scale is 50, any average below that number can be interpreted to represent marginally negative levels of support. ${ }^{22}$

\section{Figure 2: Presidential Approval over Time}

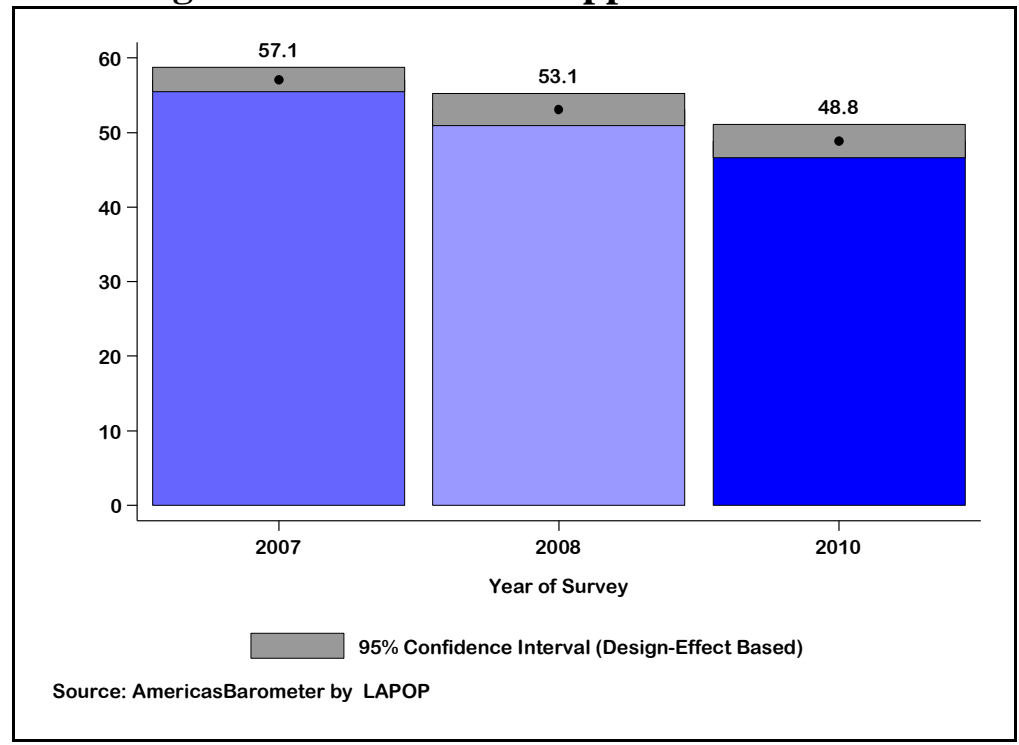

${ }^{21}$ For purposes of statistical analysis and improved presentation of results the responses are recoded into a scale $0-100$, with $0=$ very bad and $100=$ very good.

${ }^{22}$ The grey area at the top of the bars represents the confidence interval around the mean. The wider this area the greater the dispersion of responses around the mean and thus the less reliable the mean is. When the areas overlap the differences between the bars are not statistically significant. 
Erosion in support may be the result of deteriorating security and economic conditions. Studies have shown that Chávez's base of support is among the lower socio-economic groups who might be expected to be most affected by rising crime and deteriorating economic conditions, particularly a decline of purchasing power due to inflation. ${ }^{23}$ Venezuela suffers from one of the highest homicide rates in Latin America. The Venezuelan Observatory of Violence (OVV), whose data is widely followed in the absence of official statistics, said the South American nation has one of the highest crime rates on the continent, with 54 homicides per 100,000 citizens in 2009. That rate is only surpassed in Latin America by El Salvador where 70 in every 100,000 citizens were murdered in 2009. Homicides have quadrupled since President Hugo Chávez came to power, with two people murdered every hour. Caracas has now the world's highest murder rate. According to official figures reported by a survey on victimization carried out by the National Statistics Institute (INE), the Venezuelan capital has become the deadliest city in the world. A total of 7,676 people were killed in the Metropolitan Area of Caracas in 2009. According to this survey, the murder rate in the Venezuelan capital was 233 per 100,000 inhabitants. ${ }^{24}$

\footnotetext{
${ }^{23}$ Damarys Canache, "Urban Poor and Political Order." in Jennifer L. McCoy and David Myers (eds), The Unraveling of Representative Democracy in Venezuela, (Baltimore, MD: John's Hopkins University Press, 2004), p. 33-49; Barry Cannon, "Class/Race Polarisation in Venezuela and the Electoral Success of Hugo Chávez: A Break with the Past of the Song Remains the Same?" Third World Quarterly 29(4) 2008: 731-748; Oliver Heath "Explaining the Rise of Class Politics in Venezuela." Bulletin of Latin American Research 28(2) 2009: 185-203; Noam Lupu, "Who Votes for Chavismo? Class Voting in Hugo Chavez's Venezuela." Latin American Research Review 45(1) 2010: 7-32.

${ }^{24}$ Data on homicide rates are notoriously difficult to ascertain. Other surveys point to a rate in Caracas of 140 per 100,000 inhabitants.
} 
Figure 3 compares homicide rates of selected Latin American countries and shows the increase in violence in Venezuela relative to other nations. Particularly relevant is the decline in homicides in Colombia versus the increase in Venezuela.

Figure 3: Homicide Rates per 100,000 inhabitants, selected Latin American Countries

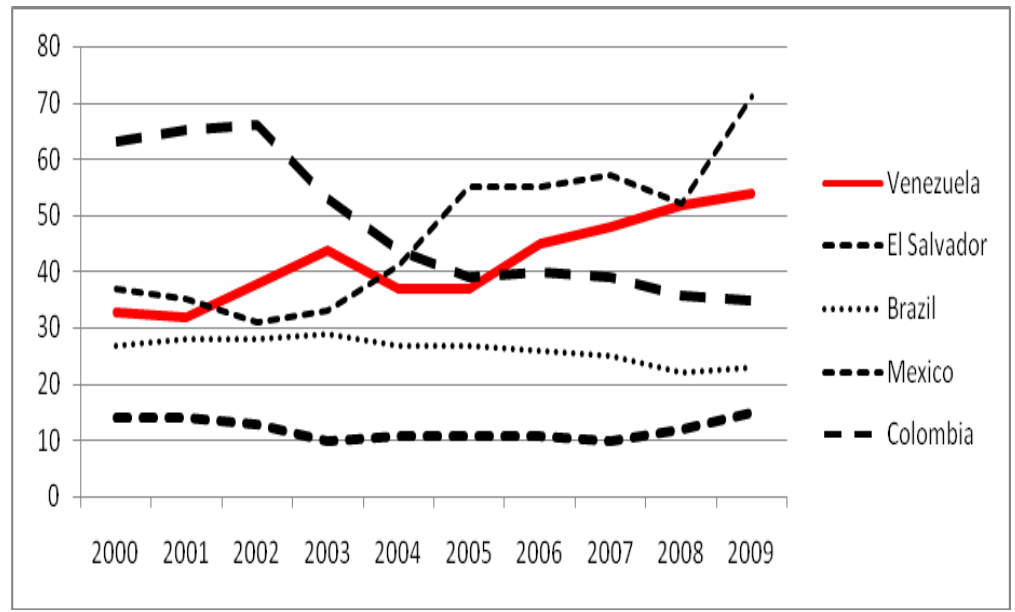

Another factor that may influence the decline in presidential approval is the deterioration of the economy. As a major oil producer, Venezuela benefitted from the rise in world oil prices that began in 2004. Fueled by the windfall from oil price increases, the Venezuelan economy grew by over 18 percent in 2004, about 10 percent in 2005 and 2006, 8.2 percent in 2007, and 4.8 percent in 2008. The country's GDP growth began to slow in the second quarter of 2008 and turned negative in the first quarter of 2009. High levels of

Regardless of the actual number, the reality is that Caracas is among the most violent cities in the world. 
inflation, averaging 30 percent in 2008, 27 percent in 2009, and 28 percent in 2010 , have also eroded purchasing power.

\section{Figure 4: GDP Growth $(\%)$ in Venezuela, 2001-2010 ${ }^{25}$}

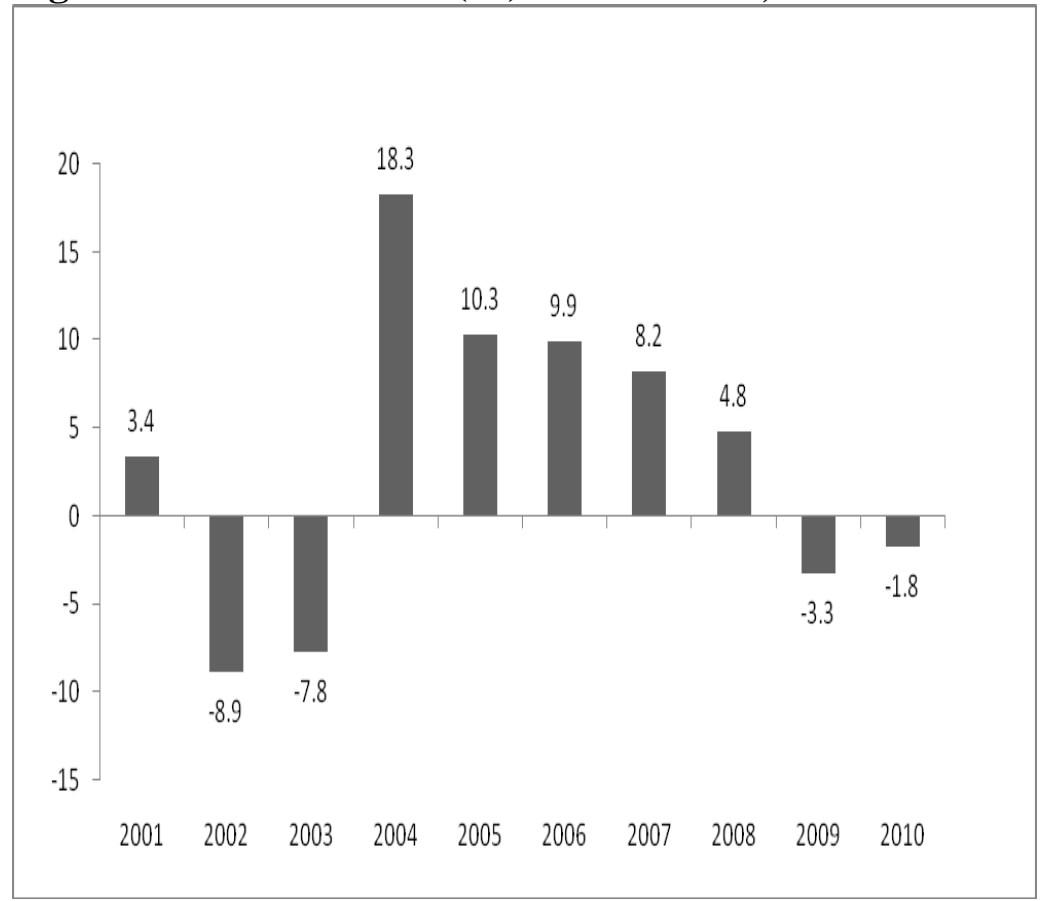

The AmericasBarometer survey allows us to examine which factors explain approval of the job performed by President Chávez. In order to do so, we employ a multivariate regression analysis which examines the impact of a series of independent variables on our dependent variable, in this case presidential approval. As independent variables I use some of the standard demographic variables: age, gender, wealth, education, and area of residence. In addition, I employ

${ }^{25}$ U.N. Economic Commission for Latin America and the Caribbean (UNCLA), Economic Survey of Latin America and the Caribbean, (Santiago, Chile, 2010). 
measures of crime victimization, perception of insecurity, evaluation of the national and personal economic condition, along with a measure of levels of utilization of the government's mission programs. Appendix one lays out how each variable is operationalized. Figure 5 displays graphically the results of the regression analysis. ${ }^{26}$

\section{Figure 5: Determinants of Satisfaction with the Job Performed by President Chávez}

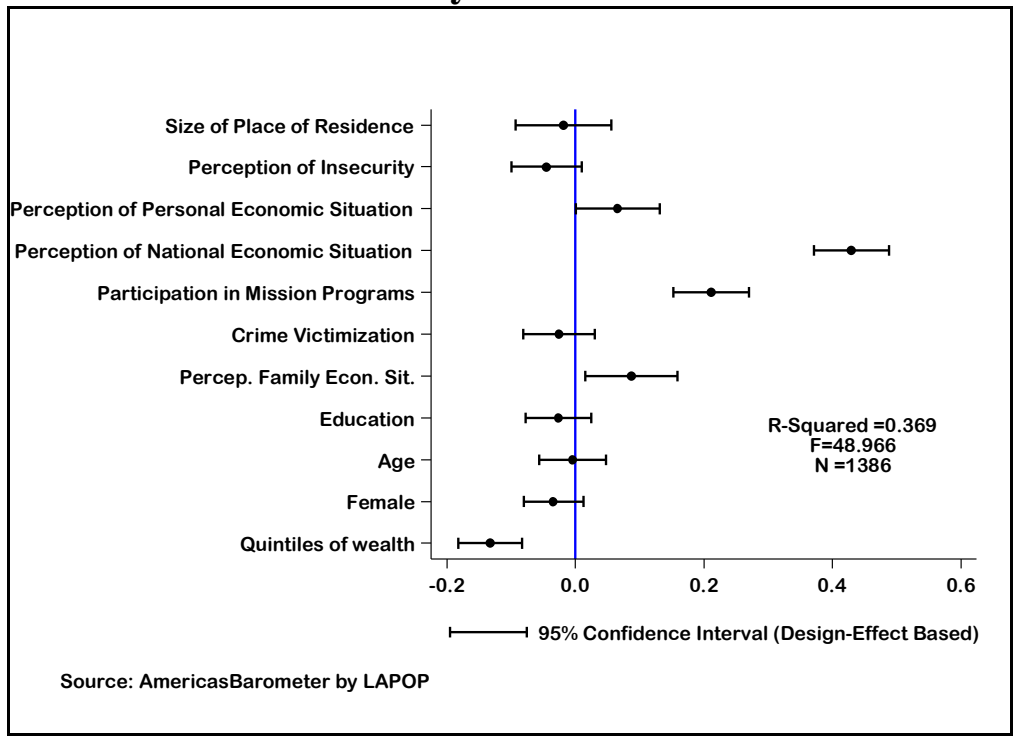

The results indicate three factors as the most important in explaining approval of the job performed by the president: perception of the national economic situation, participation in government mission programs, and levels of wealth.

${ }^{26}$ Statistical significance is graphically represented by a confidence interval that does not overlap the vertical " 0 " line (at .05 or better). When the dot, which represents the predicted impact of that variable, falls to the right of the vertical " 0 " line it implies a positive relationship whereas if it falls to the left it indicates a negative contribution. Appendix 2 shows the regression coefficients. 
Despite high levels of violence, crime victimization and perception of insecurity are not statistically significant factors.

Individuals who believe the national economy is doing well, have participated most in government missions, and are poorer are more inclined to express greater support for the president. Figure 6 shows the bivariate relationship between the three factors and satisfaction with the job of the president. As illustrated in the graphs, levels of presidential approval increase significantly for those individuals who have participated in the mission programs. The increase in presidential approval is close to 20 points. Respondents who evaluate the national economic conditions as "very good" approve of the president's job by nearly 50 points higher than individuals who believe the economy is doing very poorly. Finally, the poorest Venezuelans approve of the president's performance by nearly 15 points higher than the wealthiest citizens. 


\section{Figure 6: Factors that Determine Satisfaction with the President's Job Performance}

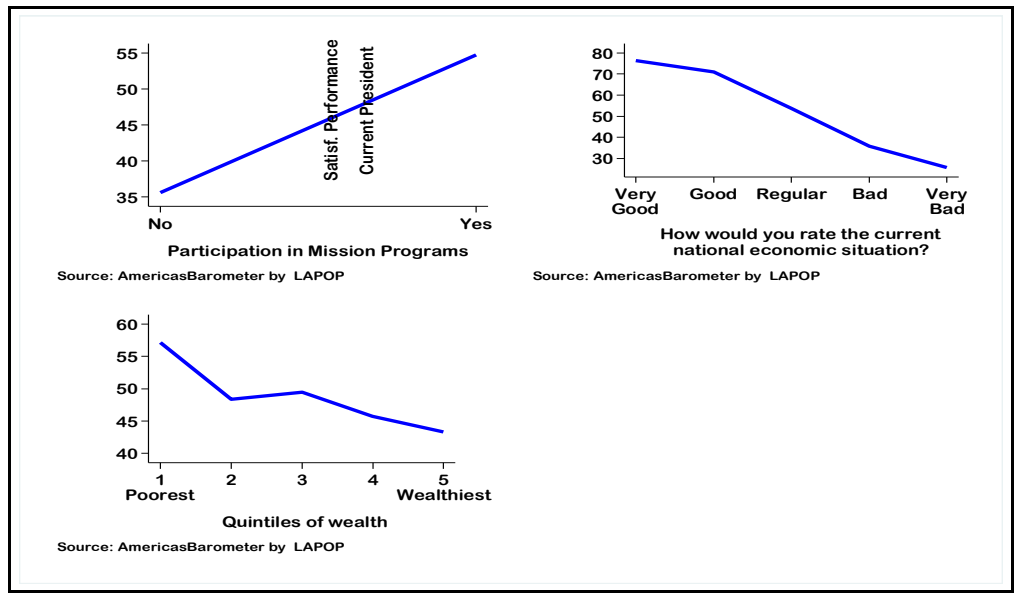

The results suggest that the government's signature programs, the social missions (Misiones Sociales) are a key element in preserving support for the regime. Financed primarily through oil revenues there have been some 25 missions offering a wide array of services in the fields of education, health, nutrition, the environment, sports, culture, and housing, as well as targeted programs for indigenous rights and services for street children, adolescents, and mothers at risk. The AmericasBarometer 2010 survey asked specifically about four of the most important missions: MERCAL, Barrio Adentro, Ribas and Madres del Barrio. MERCAL provides subsidized food through state owned supermarkets, and additional services to children, the elderly and those living in poverty. Evidence from the survey, however, suggests that MERCAL is utilized by many Venezuelans, including those in the middle classes. Barrio Adentro is a mission aimed at providing access to health care and initially relied heavily on Cuban doctors. Ribas provides high school degrees to adults and at risk youths. Finally, 
Madres del Barrio provides family planning advice, vocational training and loans to mothers from the poorest communities.

\section{Figure 7: Participation in Social Missions,} 2010

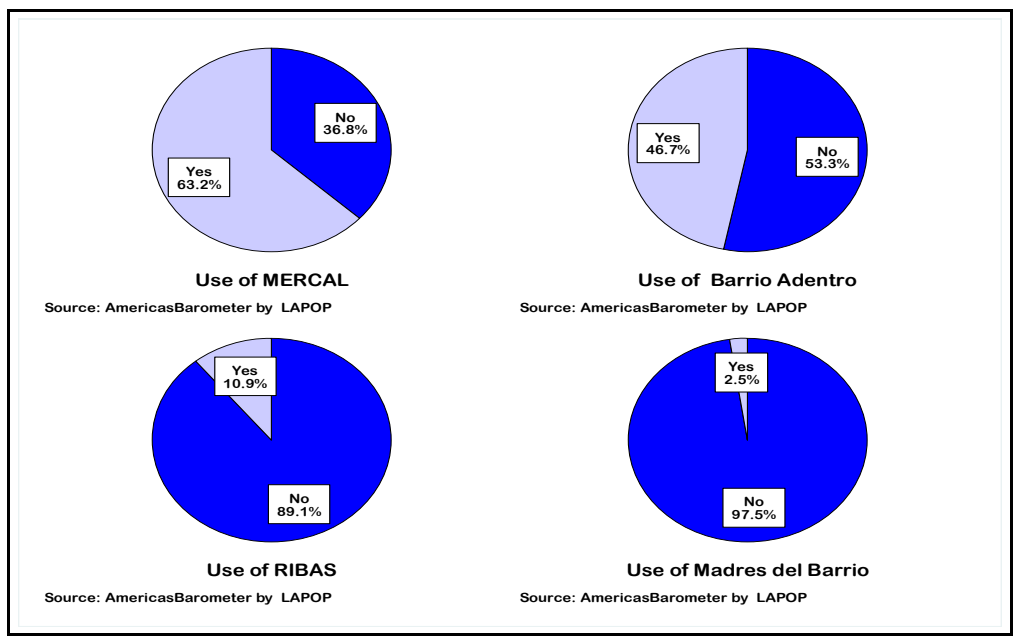

Figure 7 indicates the percent of citizens who said they had participated in the specific missions in the last 12 months. We observe that participation is most extensive in MERCAL, the subsidized supermarkets, with over 60 percent of Venezuelans saying they have used these services. Such large participation would indicate that even middle class Venezuelans have sought the help of these supermarkets to subsidize their purchase of food items. Given the high levels of inflation and the recent shortages of basic food items, it should not be a surprise that a substantial number of Venezuelans seek help by using MERCAL. The next highest level of participation is in the health delivery mission Barrio Adentro. Over 46 percent of Venezuelans say they have used these services in the last 12 months. Much 
lower participation is found for mission Ribas and Madres del Barrio, only 11 and 2.5 percent respectively.

\section{Figure 8: Overall Participation in Social Missions}

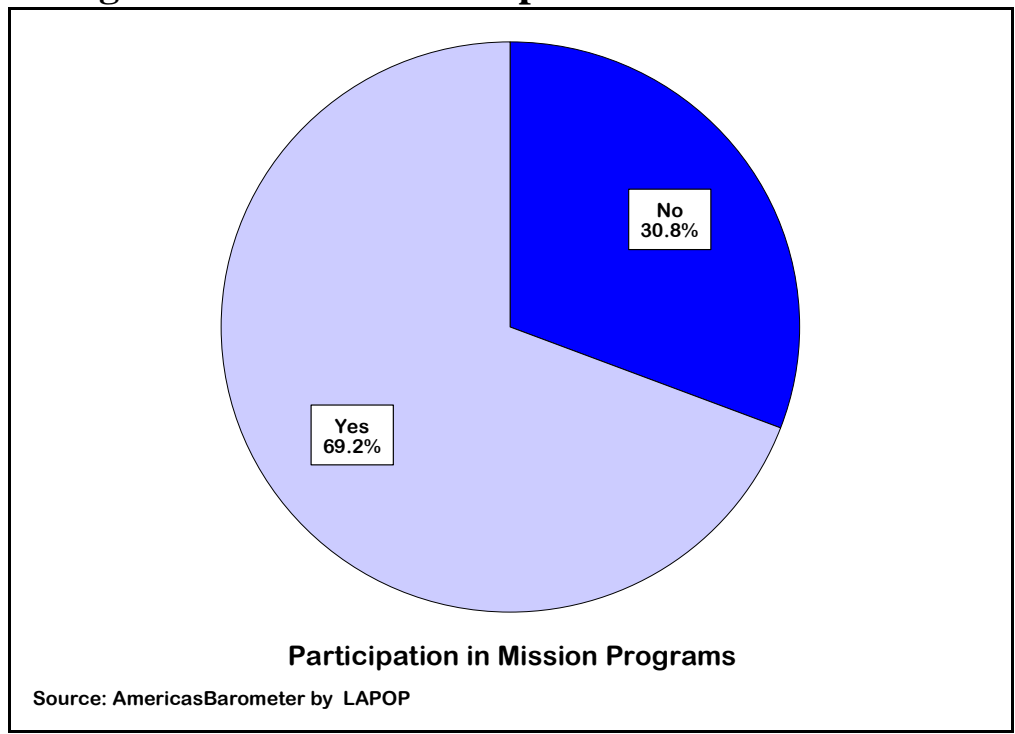

Overall, Figure 8 indicates that 69.2 percent of Venezuelans surveyed in 2010 said they participated in at least one social mission in the past 12 months. These results suggest that as long as the government is able to fund the social missions, particularly MERCAL and Barrio Adentro, it will possess an important tool to garner and sustain support for President Chávez.

Our analysis, however, also indicates that evaluations of the national economic situation, more than crime or insecurity, are a key factor that could undermine support for the regime. 


\section{Figure 9: Evaluation of the National Economic Situation,}

$2010^{27}$

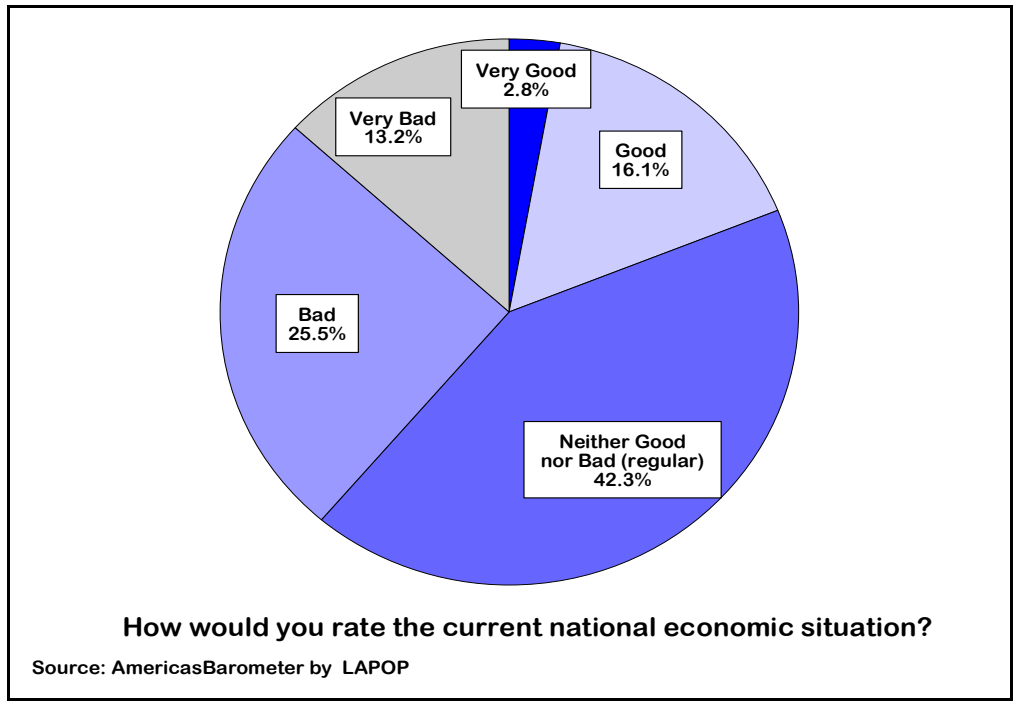

Figure 9 shows that a plurality of Venezuelans in 2010 evaluated the economic situation as "neither good, nor bad" or "regular," with 42.3 percent choosing this option. A nearly equal percentage of citizens, 39 percent, evaluate the economy as bad or very bad. Only 18.9 percent express positive evaluations of the national economic situation.

The evidence suggests that evaluations of the national economic situation have eroded since 2007, corresponding to a decline in the percentage of GDP growth and rising

${ }^{27}$ The question used is: SOCT1. Ahora, hablando de la economía... ¿Cómo calificaría la situación económica del país? ¿Diría usted que es muy buena, buena, ni buena ni mala, mala o muy mala? (1) Muy buena (2) Buena (3) Ni buena, ni mala (regular) (4) Mala (5) Muy mala (pésima)』 translated as: Now, talking about the economy..How would you describe the national economy? Would you say it is very good, good, neither good nor bad or very bad?] 
inflation. Figure 10 indicates a steady decline in the evaluations of the national economic situation.

\section{Figure 10: Perception of National Economic Situation} over Time $^{28}$

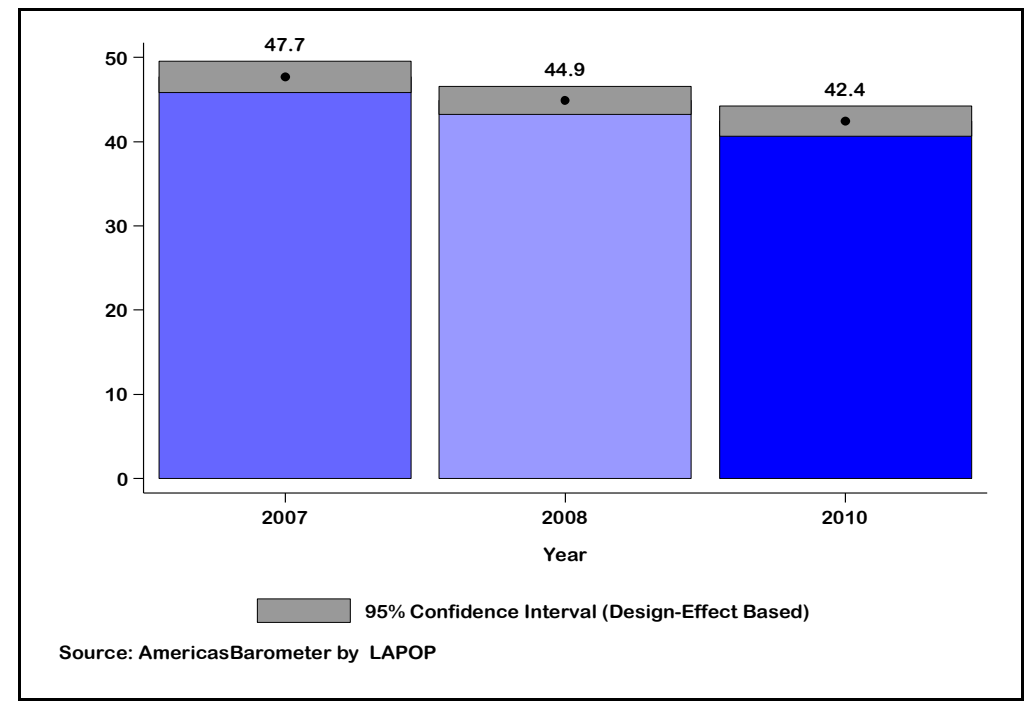

The results reflect a generally neutral evaluation of the national economic situation. Unfortunately, we do not have survey data for years prior to 2007, a year which saw significant economic growth but well below the highs of 2004. By 2008 the economy had begun a rapid contraction which saw declines in GDP growth of -3.3 in 2009 and -1.8 in 2010. These years, as seen earlier, saw a significant rise in inflation reaching close to 30 percent in 2008-2010.

\footnotetext{
${ }^{28}$ These results are obtained by recoding the SOCT1 question into a 0100 scale, where $0=$ very negative evaluations and $100=$ very positive evaluations.
} 
Figure 11: Magnitude of Economic Crisis, 2010

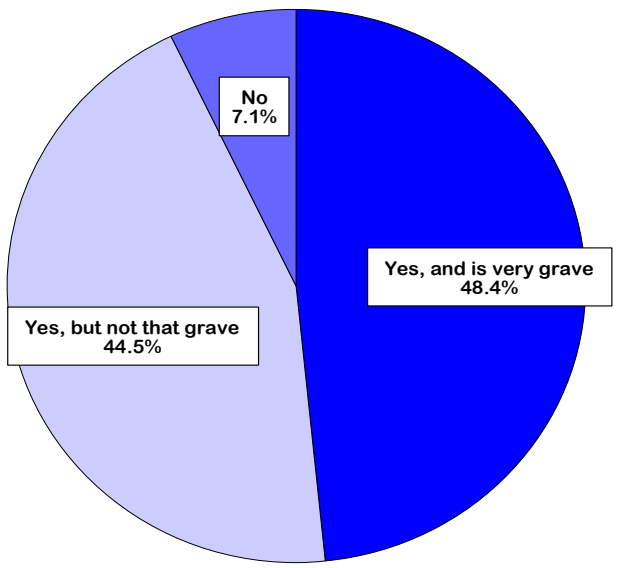

Country suffering an economic crisis?

Source: AmericasBarometer by LAPOP

The AmericasBarometer 2010 survey asked respondents to evaluate the extent of the economic crisis confronting the country. Figure 11 demonstrates that only 7.1 percent of Venezuelans say the country is not suffering an economic crisis. An overwhelming 92.9 percent of citizens interviewed indicated the country was suffering an economic crisis, 44.5 percent of those said the crisis was not grave. Additionally, when citizens are asked who they blame for the economic crisis most choose the current government. 


\section{Figure 12: Who is to blame for the current economic crisis?}

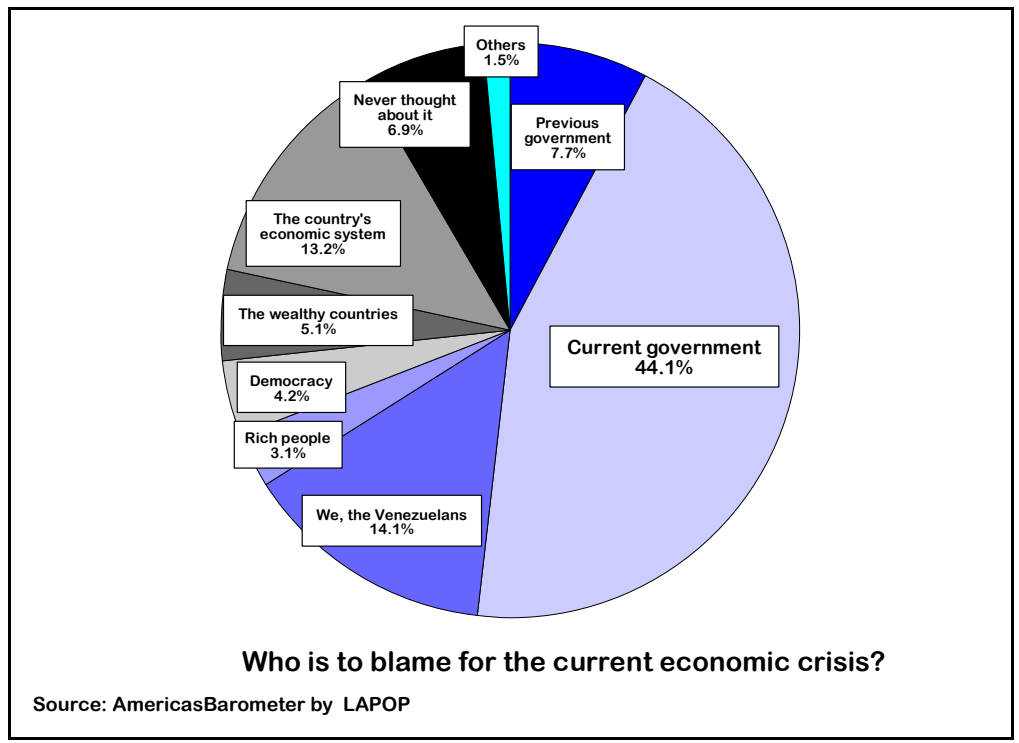

We observe in Figure 12 that 44.1 percent of Venezuelans blame the Chávez government for the economic crisis. Only 5.1 percent blame the "wealthy countries" and 3.1 percent the "rich" people of Venezuela.

Finally, Figure 13 demonstrates the clear connection between evaluations of the economy and presidential approval. Individuals who believe the country is not suffering an economic crisis express significantly higher support for President Chávez than those who believe the economy is suffering a grave economic crisis. The difference is more than 40 points. 


\section{Figure 13: Perceptions of Economic Crisis and Presidential Approval}

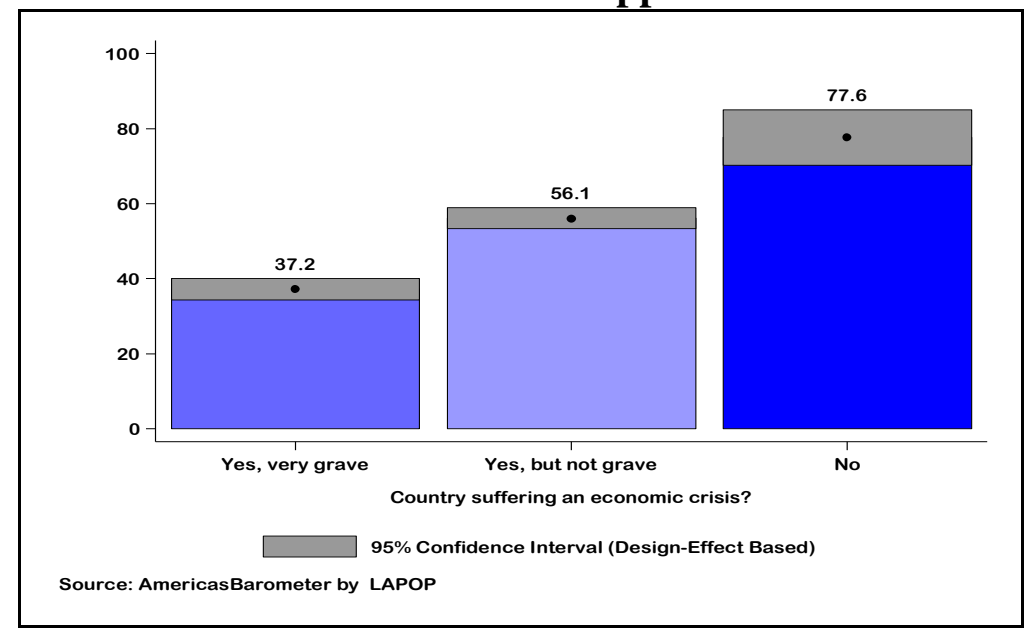

\section{CONCLUSION}

Since coming to power in 1999 Hugo Chávez has transformed the political landscape of Venezuela. He dismantled the institutional structures of liberal democracy and implemented a system that he calls participatory, but that relies heavily on Chávez's personal authority. The system depends on support from a large mass of poor Venezuelans disaffected from the previous political system and clamoring for political, social and economic empowerment. The regime has used oil revenues to build a system of social programs aimed at providing basic services to the poorest sectors of Venezuelan society. Chávez has been able to combine incendiary rhetoric against the United States and European powers, as well as wealthy Venezuelans, along with substantial government subsidies to garner and maintain sufficient popular support to win all but one electoral contest 
since 1999, including winning election as president twice under the current Constitution.

This study has shown that presidential approval is influenced significantly by evaluations of the national economic situation and participation in social missions. These two may in fact be counteracting each other. That is, as the economic situation deteriorates, particularly the rising rate of inflation, support for the regime will likely decline. The evidence suggests that Venezuelans who believe the country is suffering an economic crisis support the president 40 points less than those who believe there is no economic crisis. Under these circumstances, the regime will be forced to increase subsidies through the social missions in order to bolster support. The evidence presented here suggests that the use of some social missions by Venezuelan citizens is widely generalized, including many in the middle class. The results of our study suggests that the Venezuelan government's social missions have been quite successful at building a bulwark of support that has so far allowed it to weather the economic downturn and rising levels of violence. Whether such efforts can continue, or be strengthened, remains an open question, and will depend on economic factors beyond the control of the Venezuelan government, such as oil prices.

The regime will no doubt attempt to build on the social missions as it seeks to increase support in order to guarantee Chávez another term in office in the elections of 2012. While Chávez's re-election will depend greatly on the unity and strength of the political opposition, continued economic problems and increasing violence also will be critical issues determining the future of the populist leader. 
An additional wrinkle was added in early June 2011 when, after weeks of speculation, President Chávez announced from Cuba that he was battling cancer. Chávez spent nearly a month in Cuba before returning to Venezuela on July 4. He departed for Havana once again on July 16 after petitioning Venezuela's national congress for a medical leave that allowed him to remain at the head of the government. Regime supporters insist that Chávez will recover and successfully contest the 2012 presidential elections. For the opposition, the president's illness poses opportunities and challenges. On the one hand, if the president decides not to run or dies before the elections regime supporters may struggle to find a replacement that could galvanize the masses that have supported Chávez since the late 1990s. On the other hand, the removal of Chávez may splinter the opposition by eliminating the one clear factor that has united them for the past years. No reliable polling has been done since Chávez's illness to measure what effect it may have on his popularity or prospects in 2012. One might speculate that the regime will attempt to use the president's struggle with cancer to rally popular sentiment in his favor. If for whatever reason Chávez is not the official candidate in 2012, regime supporters, assuming they can unite behind a single successor, would likely use similar tactics to rally support to "continue the revolution." While much remains uncertain about the future of the Venezuelan regime, what is clear is that the problems of rising crime and continued economic deterioration, particularly increasing inflation, along with the health of the president, represent serious and transcendental challenges to the survival of Hugo Chávez and his neopopulist experiment. 


\section{WORKS CITED}

Bridges, Tyler, "Chávez Allies Score Big Wins in Venezuela Elections," Miami Herald, November 24, 2008.

Canache, Damarys, "Urban Poor and Political Order." in Jennifer L. McCoy and David Myers (eds.), The Unraveling of Representative Democracy in Venezuela, (Baltimore, MD: John's Hopkins University Press, 2004), p. 33-49.

Cannon, Barry, "Class/Race Polarisation in Venezuela and the Electoral Success of Hugo Chávez: A Break with the Past of the Song Remains the Same?" Third World Quarterly 29(4) 2008: 731-748.

Ceresole, Norberto. "El modelo venezolano o la posdemocracia: Caudillo, apóstoles, pueblo." $E l$ Universal

Digital, (http://politica.eud.com/1999/03/08/ceresole.html), 11 January 1999.

"Chávez unmoved as officers desert," BBC News (http://news.bbc.co.uk/hi/english/world/americas/), February 26, 2002.

Crisp, Brian, Daniel H. Levine, Juan Carlos Rey, 'The Legitimacy Problem,' in J McCoy, A Serbin, W Smith, and A Stambouli, Venezuelan Democracy under Stress, (Coral Gables, FL: North-South Center, University of Miami, 1995), pp. 139-172.

Forero, Juan, "Chávez Wins Removal of Term Limits," Washington Post, February 16, 2009. 
Heath, Oliver, "Explaining the Rise of Class Politics in Venezuela." Bulletin of Latin American Research 28(2) 2009: 185-203.

Hellinger, Daniel, Venezuela, Tarnished Democracy, (Boulder, CO.: Westview Press, 1991).

Karl, Terry Lynn, 'The Venezuelan Petro-State and the Crisis of 'its' Democracy,' in Jennifer McCoy, Andres Serbin, William C. Smith, and Andres Stambouli, Venezuelan Democracy under Stress, (Coral Gables, FL: North-South Center, University of Miami, 1995).

'Petroleum and Political Pacts: The Transition to Democracy in Venezuela,' in Guillermo O'Donnell, Philippe Schmitter, and Laurence Whitehead (eds.), Transitions from Authoritarian Rule: Latin America, (Baltimore. MD: Johns Hopkins University Press, 1986)

Loveman, Brian and Thomas M. Davies (eds.), The Politics of Antipolitics: The Military in Latin America (revised and updated), (Wilmington, DE: Scholarly Resources, 1997).

Lupu, Noam, "Who Votes for Chavismo? Class Voting in Hugo Chavez's Venezuela." Latin American Research Review 45(1) 2010: 7-32.

McCoy, Jennifer, Jeff Davies, and Paul Foote, 'Reluctant Reformers: Explaining Privatization in Venezuela and Uruguay,' Paper presented at the Meeting of the Latin American Studies Association, Chicago, Ill, 1998. 
Naim, Moisés, Paper Tigers and Minotaurs: The Politics of Venezuela's Economic Reforms, (Washington, D.C.: Carnegie Endowment for International Peace, 1993).

Pérez, Orlando J., "Chavismo and the Transformation of Civil-Military Relations in Venezuela," South Eastern Latinamericanist, (Summer 2002): 12-33.

"Revolution by Numbers," Latin American Andean Group Report, Latin American Newsletters, February 2011, RA-11-02.

Romero, Simon, "Venezuelan Opposition Gains in Several Crucial Elections," New York Times, November 24, 2008.

Steffan, Heinz Dietrich, "El Socialismo del Siglo XXI" published in 2000.

Templeton, Andrew 'The Evolution of Popular Opinion,' in Louis Goodman et al, (eds.), Lessons of the Venezuelan Experience (Washington, D.C.: The Woodrow Wilson Center, 1996).

U.N. Economic Commission for Latin America and the Caribbean (ECLA), Economic Survey of Latin America and the Caribbean, (Santiago, Chile, 2010).

"Venezuela Country Report," Economist Intelligence Unit (EIU) November 2010.

Villasmil, Nelson La Opinión pública del venezolano actual, (Caracas: UCAB/Cátedra Fundacional Carlos E. Frías, 2000). 


\section{APPENDIX 1}

\section{Measurement of Variables}

\begin{tabular}{|c|c|}
\hline $\begin{array}{l}\text { Presidential job } \\
\text { approval }\end{array}$ & $\begin{array}{l}\text { M1. Y hablando en general del actual gobierno, } \\
\text { ¿diría usted que el trabajo que está realizando el } \\
\text { Presidente [NOMBRE PRESIDENTE ACTUAL] } \\
\text { es...?: }\end{array}$ \\
\hline $\begin{array}{l}\text { Size of Place of } \\
\text { Residence }\end{array}$ & $\begin{array}{l}\text { TAMANO. (1) Capital nacional (área } \\
\text { metropolitana) (2) Ciudad grande (3) Ciudad } \\
\text { mediana (4) Ciudad pequeña (5) Área rural }\end{array}$ \\
\hline $\begin{array}{l}\text { Perception of } \\
\text { personal economic } \\
\text { situation }\end{array}$ & $\begin{array}{l}\text { IDIO1. ¿Cómo calificaría en general su situación } \\
\text { económica? ¿Diría usted que es muy buena, } \\
\text { buena, ni buena ni mala, mala o muy mala? } \\
\text { (1) Muy buena (2) Buena (3) Ni buena, ni mala } \\
\text { (regular) (4) Mala } \\
\text { (5) Muy mala (pésima) (88) NS (98) NR }\end{array}$ \\
\hline $\begin{array}{l}\text { Perception of } \\
\text { national economic } \\
\text { situation }\end{array}$ & $\begin{array}{l}\text { SOCT1. Ahora, hablando de la economía... } \\
\text { ¿Cómo calificaría la situación económica del país? } \\
\text { ¿Diría usted que es muy buena, buena, ni buena ni } \\
\text { mala, mala o muy mala? (1) Muy buena (2) Buena } \\
\text { (3) Ni buena, ni mala (regular) (4) Mala (5) Muy } \\
\text { mala (pésima) (88) NS (98) NR }\end{array}$ \\
\hline $\begin{array}{l}\text { Participation in } \\
\text { Mission Programs }\end{array}$ & 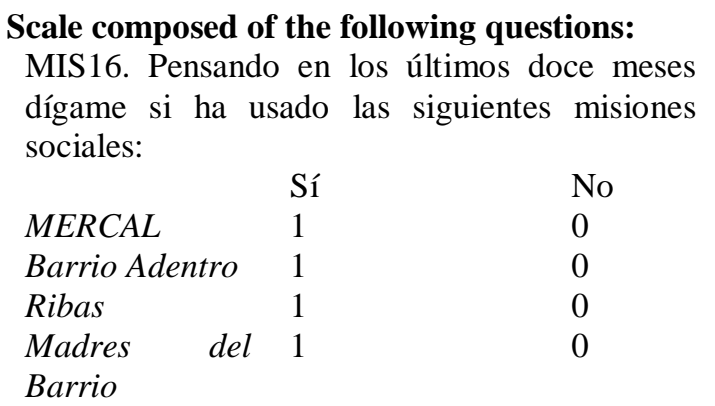 \\
\hline
\end{tabular}




\begin{tabular}{|c|c|}
\hline Education & $\begin{array}{l}\text { ED. ¿Cuál fue el último año de enseñanza que } \\
\text { usted completó o aprobó? }\end{array}$ \\
\hline Gender & $\begin{array}{l}\text { Q1. Género (anotar, no pregunte): (1) Hombre } \\
\text { (2) Mujer }\end{array}$ \\
\hline Age & Q2. ¿Cuál es su edad en años cumplidos? \\
\hline Crime victim & $\begin{array}{l}\text { VIC1. Ahora, cambiando el tema, ¿Ha sido usted } \\
\text { víctima de algún acto de delincuencia en los } \\
\text { últimos } 12 \text { meses? }\end{array}$ \\
\hline $\begin{array}{l}\text { Perception of } \\
\text { Insecurity }\end{array}$ & $\begin{array}{l}\text { AOJ11. Hablando del lugar o barrio/colonia } \\
\text { donde usted vive, y pensando en la posibilidad de } \\
\text { ser víctima de un asalto o robo, ise siente usted } \\
\text { muy seguro, algo seguro, algo inseguro o muy } \\
\text { inseguro? }\end{array}$ \\
\hline Wealth & $\begin{array}{l}\text { Measured as a scale of possession of capital goods } \\
\text { but based on relative wealth. For more information } \\
\text { on this indicator, see: Córdova, Abby B. } 2009 \\
\text { "Methodological Note: Measuring Relative } \\
\text { Wealth using Household Asset Indicators." In } \\
\text { AmericasBarometer Insights Series. } \\
\text { (http://www.vanderbilt.edu/lapop/insights.php). }\end{array}$ \\
\hline $\begin{array}{l}\text { Perception of } \\
\text { Family Economic } \\
\text { Situation }\end{array}$ & $\begin{array}{l}\text { Q10D. El salario o sueldo que usted recibe y el } \\
\text { total del ingreso de su hogar: [Leer alternativas] } \\
\text { (1) Les alcanza bien y pueden ahorrar } \\
\text { (2) Les alcanza justo sin grandes dificultades } \\
\text { (3) No les alcanza y tienen dificultades } \\
\text { (4) No les alcanza y tienen grandes dificultades } \\
\text { (88) [No leer] NS } \\
\text { (98) [No leer] NR }\end{array}$ \\
\hline
\end{tabular}




\section{APPENDIX 2}

\section{Determinants of Satisfaction with bPerformance of Current President}

\begin{tabular}{|l|c|c|}
\hline \multicolumn{2}{|c|}{ Dependent Variable: Satisfaction with Performance Current } \\
President & Coefficient. \\
\hline Quintiles of wealth & $\mathbf{- 0 . 1 3 3 *}$ & $(-5.37)$ \\
\hline Female & -0.034 & $(-1.46)$ \\
\hline Age & -0.004 & $(-0.15)$ \\
\hline Education & -0.026 & $(-1.03)$ \\
\hline $\begin{array}{l}\text { Perception of Family } \\
\text { Economic Situation }\end{array}$ & $\mathbf{0 . 0 8 7} *$ & $(2.44)$ \\
\hline Crime Victimization & -0.025 & $(-0.90)$ \\
\hline $\begin{array}{l}\text { Participation in Mission } \\
\text { Programs }\end{array}$ & $\mathbf{0 . 2 1 1 *}$ & $(7.20)$ \\
\hline $\begin{array}{l}\text { Perception of National } \\
\text { Economic Situation }\end{array}$ & $\mathbf{0 . 4 3 0} *$ & $(14.80)$ \\
\hline $\begin{array}{l}\text { Perception of Personal } \\
\text { Economic Situation }\end{array}$ & $\mathbf{0 . 0 6 6} *$ & $(2.04)$ \\
\hline Perception of Insecurity & -0.045 & $(-1.65)$ \\
\hline $\begin{array}{l}\text { Size of area of } \\
\text { residende }\end{array}$ & -0.019 & $(-0.51)$ \\
\hline Constant & -0.004 & $(-0.12)$ \\
\hline R-Squared & 0.369 & \\
\hline Number of Obs. & 1386 & \\
\hline * p<0.05 & & \\
\hline
\end{tabular}




\section{ABOUT THE AUTHOR}

Orlando J. Pérez is a professor and chairperson of the department of political science at Central Michigan University. His conference presentations and publications have focused on democratization, elite theory, authoritarianism, public opinion, U.S.-Panama relations, and civil-military relations. He is a recipient of a grant from the United States Institute of Peace for his project studying the transformation of civil-military relations in post-authoritarian Central America. He has carried out field research in several countries of the region, including Panama, Nicaragua, El Salvador, Guatemala, Honduras, and Venezuela. His current research focuses on civil-military relations in Latin America, crime and security issues in Central America, as well as survey research on democratic political culture. His work has appeared in several prestigious journals. He is the editor of Post-Invasion Panama: The Challenges of Democratization in the New World Order (Lexington Books, 2000), and coeditor of Latin American Democracy: Emerging Reality or Endangered Species? (Routledge, 2009). He recently published: Political Culture in Panama: Democracy after Invasion (New York, NY: Palgrave-MacMillan, 2011). As a consultant, he has worked on public opinion surveys, democratization, civil-military relations, and corruption issues for USAID and the UN Development Program. Additionally, he is a member of the Scientific Support Group for the Latin American Public Opinion Project (LAPOP) at Vanderbilt University. Dr. Pérez is serving as co-chair of the defense, public security and democracy section of the Latin American Studies Association (LASA) and is a member of the international advisory board of the research committee on armed forces \& society of the International Political Science Association (IPSA). He is a past president of the Midwest Association for Latin American Studies (MALAS). 
Dr. Pérez received a M.A. and Ph.D. in political science from the University of Pittsburgh. 


\section{WHEMSAC PUBLICATIONS}

\section{PHASE I}

Adriana Moreno Blanco, "Food Security in Latin America," August 2011.

J. Mark Ruhl, “Guatemala: A Failing State?” July 2011.

Hugo Corrales Compagnucci, "Armed Groups and Violence in Paraguay." July 2011.

Luis Bitencourt, "The Security Challenges for the 2016: Rio de Janeiro Olympic Games.” July 2011.

Carmen Rosa de León-Escribano, "Capabilities of Police and Military Forces in Central America: A Comparative Analysis of Guatemala, El Salvador, Honduras and Nicaragua." July 2011.

Rodolfo F. Robles-Montoya, "The Use of the Military for Law Enforcement Activities in Central America.” June 2011.

Ivelaw Lloyd Griffith, “The Re-Emergence of Suriname's Désiré (Desi) Bouterse: Political Acumen and Geopolitical Anxiety." June 2011.

Paola Prado, "The Impact of the Internet in Six Latin American Countries.” June 2011.

Harold Trinkunas, "International Bolivarianism and its Influence.” June 2011.

David Scott Palmer and Alberto Bolívar, "Peru's Shining Path: Recent Dynamics and Future Prospects." May 2011. 
Erich de la Fuente, “ALBA: A Political Tool for Venezuela's Foreign Policy." May 2011.

Norman Munroe, "Climate Change and Regions at Risk: A Look at Central America.” May 2011.

Juan Pablo Sarmiento \& Gabriela Hoberman, "Disaster Risk Management Disparity in the Caribbean: Evidence from Barbados, Dominican Republic, Jamaica and Trinidad and Tobago.” May 2011.

Daniel E. Moreno, “The Indigenous in Plurinational Bolivia: Perceptions of Indigenous People in Bolivia Before and During the Morales Government.” April 2011.

Raúl L. Madrid, "Indigenous Movements, Democracy, and U.S. Interests in Latin America.” April 2011.

Thomas Bruneau, "An Analysis of the Implications of Joint Military Structures in Argentina, Brazil, Chile, and Colombia.” April 2011.

Rut Diamint, Pablo Policzer and Michael Shifter, "Latin American Coups: Have They Vanished or Taken New Shapes?" March 2011.

Antonio L. Mazzitelli, "The New Transatlantic Bonanza: Cocaine on Highway 10.” March 2011.

Carlos Pereira, "Brazil Under Dilma Rousseff: Similar Policy Directions Maintained.” March 2011.

Patricio Navia, "Venezuela and Chile: Two opposite Paths of Democratic Consolidation and Economic Development." March 2011. 
Miguel L. Castillo-Girón, "Land Ownership Transfers in Petén, Guatemala." February 2011.

ARC, "Latin America and the Caribbean in 2011 and Beyond.” February 2011.

Iñigo Guevara Moyano, "Defense Expenditures: Argentina, Chile, Uruguay, and Paraguay.” December 2010.

Bradley S. Porter, "Altered Landscapes or Arms Race? Making Sense of Military Spending in South America." November 2010.

Iñigo Guevara Moyano, "Defense Expenditure: Andean and Amazon Regions." November 2010.

Ambassador Peter DeShazo, "Consolidating Security and Development in Colombia: Lessons for Peru and Panama." November 2010.

Johanna Mendelson-Forman, "South American Defense Council: What it means for regional security?" November 2010.

Erich de la Fuente, "Cuba's Role in Venezuela's Control of the Internet and Online Social Networks." October 2010.

Marifeli Perez-Stable, "Raul Castro's Government: Recent Economic Reforms and Some Political Considerations." October 2010.

Iñigo Guevara Moyano, "Defense Expenditures: Central America and Dominican Republic." September 2010. 
Hal Brands, "Criminal Fiefdoms in Latin America: Understanding the Problem of Alternatively Governed Spaces." September 2010.

ARC, "Honduras' Stressed Social Fabric: Instability and Risks.” August 2010.

CTC and ARC, "Uranium in Latin America: Reserves, Energy, and Security Implications.” August 2010.

John Proni, "Independent Monitoring of the Cuban Economic Zone Oil Development.” July 2010.

Kristina Mani, "Military Entrepreneurship in Latin America: A Brief Overview." June 2010.

Bruce Bagley and Olga Nazario, "Lithium and Bolivia: The Promise and the Problems." June 2010.

Brian Fonseca, "Domestic Politics in the Dominican Republic after the Earthquake in Haiti." June 2010.

\section{PHASE I}

Brian Fonseca, "Human Smuggling \& The TerroristCriminal Nexus.” January 2009.

Arturo Contreras and Francisco Ledantec, "General Overview of Transnational Threats in Latin America with a Special Focus in South America \& Its Effect on International Security and US-Latin American Relations." December 2008.

Thomas Bruneau, "Civil Military Relations in Democratic Latin America.” December 2008. 
Brian Fonseca, "Identifying Opportunities for US-Cuba Military Cooperation.” December 2008.

Harold A. Trinkunas, "Understanding Venezuelan Strategic Culture." December 2008.

Joanna Mateo, "US-Brazil: Forging a New Relationship." November 2008.

Joanna Mateo, “Las Maras in Honduras.” November 2008.

Joanna Mateo, "Advancing Security Cooperation in the Americas: An Historical Perspective.” August 2008.

Julio A. Cirino, "The Media Component in a Visual Culture and the Spread of Populism in Latin America: Exploring the Spiral of Silence." June 2008.

Brian Fonseca and Evan Ellis, "Emerging Relationships: China and Latin America." May 2008.

Joanna Mateo, "Gang Violence in Central America: The Case of Honduras. Identifying a Role for USSOUTHCOM." April 2008.

Anthony P. Maingot, "The New Geopolitics of the Andes: The Dangers of a State-on-State War.” April 2008.

Joanna Mateo, "Health Threats to Stability in the Americas." February 2008.

Brian Fonseca, "Emerging Relationships: Iran \& Latin America." February 2008.

Brian Fonseca, “Energy Outlook: Brazil.”J January 2008. 
NOTES: 
NOTES: 
NOTES: 


\section{WESTERN HEMISPHERIC SECURITY ANALYSIS CENTER SPONSORS}

The Applied Research Center advances the research and academic mission of Florida International University. ARC's focus is to solve real-world problems through multi-disciplinary research collaborations within the University's increasingly talented applied and basic research units. It is uniquely structured and staffed to allow for free-flowing exchange of ideas between the University's applied researchers, academia, government, private sector and industry partners. The ARC's vision is to be the leading international university-based applied research institution providing value-driven, real-world solutions, which will enable FIU to acquire, manage, and execute educationally relevant and economically sound research programs. That vision is based on the Center's core values of respect for the environment, health and safety of all individuals, creativity and innovation, service excellence, and leadership and accountability. The Applied Research Center is organized into three core research units: Environment; Energy, and Security and Development. Under the leadership of its Executive Director, the Center reports to FIU's Office of Sponsored Research Administration. An External Advisory Board, encompassing leaders from the private and public sectors, participates actively in the Center's growth and development. The Florida International University Applied Research Council, a team of University deans, executives and faculty guide the development of the Center's programs.

Florida International University is Miami's first and only four-year public research university with a student body of more than 40,000. It is one of the 25 largest universities in the nation. FIU's colleges and schools offer nearly 200 bachelor's, master's and doctoral programs in fields such as international relations, law and engineering. As one of South Florida's anchor institutions, FIU has been locally and globally engaged for more than four decades finding solutions to the most challenging problems of our time. FIU emphasizes research as a major component of its mission. The opening of the Herbert Wertheim College of Medicine in August 2009 has enhanced the university's ability to create lasting change through its research initiatives. Overall, sponsored research funding for the university (grants and contracts) from external sources for the year 2008-2009 totaled approximately $\$ 101$ million.

The United States Southern Command (USSOUTHCOM) is one of ten unified Combatant Commands (COCOMs) in the Department of Defense. It is responsible for providing contingency planning, operations, and security cooperation for Central and South America, the Caribbean, and their territorial waters; as well as for the force protection of U.S. military resources at these locations.

The National Defense Center for Energy and the Environment (NDCEE) provides reliable and sustainable solutions to the US Department of Defense in areas ranging from contingency operations to global climate change and greenhouse gas reduction to safety and occupational health. These solutions increase mission readiness and improve the health and safety of our Armed Forces both at home and abroad. The NDCEE provides project management and technical support to the WHEMSAC Program. 


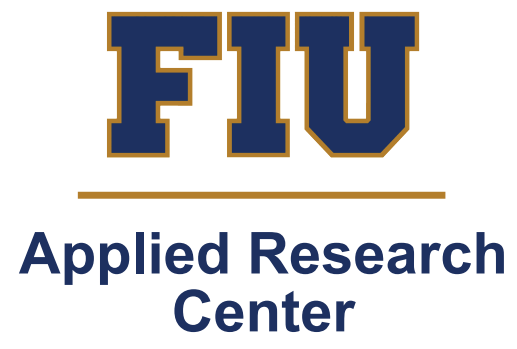

